\title{
FOREWORD BY THE DONOR, THE SANTA AGUILA FOUNDATION
}

\begin{abstract}
A beach is not just a pile of sand for us to enjoy, and we hope this book will unveil some of the mysteries of this narrow strip of nature caught between land and sea. Beaches are the most dynamic features on earth, constantly changing shape and providing vital ecological functions and a home to environments of amazing biodiversity. Understanding the importance of the beach's role vis-à-vis the land, the nearshore, and the ocean and its biodiversity is crucial to its protection and preservation.

Sadly, the beauty of our coastlines and the survival of their ecosystems are under threat. America is now facing the repercussions of the BP oil spill, the largest manmade natural disaster in U.S. history. But spills are a global issue, as recently demonstrated in China, Brazil, Nigeria, Mexico, and France. Pollution, overdevelopment, poor coastal management, and constant human interference, including beach-sand mining and seawall construction, endanger coastlines and beaches everywhere. The rise of the sea level has accelerated natural erosion and will result in a substantial loss of infrastructure. This will have an impact on all living beings, but it is our children and future generations who will be most affected.
\end{abstract}

The Santa Aguila Foundation is a U.S. nonprofit organization dedicated to the preservation of coastlines around the world. It was created after the foundation's founders witnessed the destruction of the beautiful beaches of Morocco to sand mining, a common practice around the world that is largely ignored by the media and unknown to the public at large. Since then, the foundation has focused its energy on global coastal issues (a reflection of the interconnectedness of the planet) and education; the combination of 
these two elements makes our work unique. We believe that education is key: the more knowledgeable we become about our beaches and coastlines, the deeper our bond with them and the more firm our willingness to protect these endangered natural habitats.

The mission of the foundation is to raise awareness and mobilize individuals to address the practices that are harming the world's beaches and coastlines; to educate children about the scientific aspects of natural beaches and coastlines and thus empower them to act to protect their coastal environment; and to advocate sensible, science-based policies and regulations that will protect and preserve beaches and coastlines around the world.

The Santa Aguila Foundation is honored to have made The World's Beaches possible, via a grant, and to be associated with the authors of this book, all highly respected coastal geologists.

We hope you will enjoy this book about beaches and take as much pride as we do in defending this unique feature of our planet.

This project was made possible thanks to the generous donation of Alvise and Andrea Chiari-Gaggia in memory of their mother, Marcella Gaggia.

Please visit www.coastalcare.org for further information.

The Santa Aguila Foundation 